\title{
Long-chain alcohol and aldehyde dehydrogenase activities in Acinetobacter calcoaceticus strain HO1-N
}

\author{
Maeve G. A. Fox, F. Mark Dickinson* and Colin Ratledge \\ Department of Applied Biology, University of Hull, Hull HU6 $7 R X, U K$
}

(Received 4 February 1992; accepted 28 May 1992)

\begin{abstract}
Three alcohol dehydrogenases have been identified in Acinetobacter calcoaceticus sp. strain HO1-N: an $\mathrm{NAD}^{+}$-dependent enzyme and two $\mathrm{NADP}^{+}$-dependent enzymes. One of the $\mathrm{NADP}^{+}$-dependent alcohol dehydrogenases was partially purified and was specific for long-chain substrates. With tetradecanol as substrate an apparent $K_{\mathrm{m}}$ value of 5.2 $\mu \mathrm{M}$ was calculated. This enzyme has a pI of 4.5 and a molecular mass of $144 \mathrm{kDa}$. All three alcohol dehydrogenases were constitutively expressed. Three aldehyde dehydrogenases were also identified: an $\mathrm{NAD}^{+}$-dependent enzyme, an $\mathrm{NADP}^{+}$-dependent enzyme and one which was nucleotide independent. The $\mathrm{NAD}^{+}$-dependent enzyme represented only $2 \%$ of the total activity and was not studied further. The $\mathrm{NADP}^{+}$-dependent enzyme was strongly induced by growth of cells on alkanes and was associated with hydrocarbon vesicles. With tetradecanal as substrate an apparent $K_{\mathrm{m}}$ value of $0.2 \mu \mathrm{M}$ was calculated. The nucleotide-independent aldehyde dehydrogenase could use either Würster's Blue or phenazine methosulphate (PMS) as an artificial electron acceptor. This enzyme represents approximately $80 \%$ of the total long-chain aldehyde oxidizing activity within the cell when the enzymes were induced by growing the cells on hexadecane. It is particulate but can be solubilized using Triton X-100. The enzyme has an apparent $K_{\mathrm{m}}$ of $0 \cdot 36 \mathrm{mM}$ for decanal.
\end{abstract}

\section{Introduction}

Acinetobacter calcoaceticus strain $\mathrm{HOl-N}$ is well known as an alkane-utilizing organism capable of growing on long-chain alkanes and their derivatives. Alkane metabolism is thought to follow the accepted pathway for monoterminal oxidation in bacteria (Makula \& Finnerty, 1968) - route (1) -

$$
-\mathrm{CH}_{3} \rightarrow-\mathrm{CH}_{2} \mathrm{OH} \rightarrow-\mathrm{CHO} \rightarrow-\mathrm{COOH}
$$

although hydroperoxides have also been proposed in an alternative route (2)

$$
-\mathrm{CH}_{3} \rightarrow-\mathrm{CH}_{2} \mathrm{OOH} \rightarrow-\mathrm{CHO} \rightarrow-\mathrm{COOH}
$$

not involving alcohols (Finnerty 1977, 1988). The organism readily oxidizes n-alkyl hydroperoxides (Finnerty et al., 1962). The present work has been concerned with long-chain alcohol and aldehyde dehydrogenases which may be involved in the mono-

\footnotetext{
* Author for correspondence. Tel. (0482) 465243; fax (0482) 465458

Abbreviations: DCPIP, dichlorophenolindophenol; PMS, phenazine methosulphate; TMPD, tetramethyl-p-phenylenediamine hydrochloride.
}

terminal oxidation of $\mathrm{n}$-alkanes and their conversion to the corresponding fatty acids.

Whilst some bacteria such as Pseudomonas aeruginosa (van der Linden \& Huybregste, 1969; Tassin et al., 1973), Pseudomonas putida (Benson \& Shapiro, 1976) and A. calcoaceticus (Tauchert et al., 1975; Jirausch et al., 1986) possess nucleotide-independent alcohol dehydrogenases, no nucleotide-independent aldehyde dehydrogenase has previously been found to be involved in longchain alkane oxidation (see Singer \& Finnerty, 1985a; Kleber et al., 1983). The nucleotide-dependent aldehyde dehydrogenases have been reviewed by Sorger $\&$ Aurich (1978). Our work presents evidence which shows that Acinetobacter sp. strain $\mathrm{HOl}-\mathrm{N}$ possesses an inducible, long-chain aldehyde dehydrogenase which is nucleotide independent and which can utilize Würster's Blue or phenazine methosulphate (PMS) as artificial electron acceptor. The high activity of this previously unknown enzyme suggests that the pathway for monoterminal oxidation of alkanes may need further study.

\section{Methods}

Culture conditions and extract preparation. Acinetobacter calcoaceticus strain HO1-N (ATCC 14987) was grown on minimal salts media 
(Jayasuriya, 1955) with $0 \cdot 1 \%(\mathrm{w} / \mathrm{v})$ yeast extract and one of the following as carbon source: $0.5 \%(\mathrm{v} / \mathrm{v}) \mathrm{n}$-hexadecane, $0.5 \%(\mathrm{w} / \mathrm{v})$ $\mathrm{n}$-hexadecanol, $1.0 \%(\mathrm{w} / \mathrm{v})$ sodium succinate, $1.0 \%(\mathrm{w} / \mathrm{v})$ sodium acetate. Stock cultures were maintained on nutrient agar slopes and subcultured into $250 \mathrm{ml}$ shake flasks containing $100 \mathrm{ml}$ of nutrient broth. After $8 \mathrm{~h}$ growth, an $8 \mathrm{ml}$ sample of this culture was transferred to a 1 litre vortex-aerated bottle containing $800 \mathrm{ml}$ of the above medium. Cultures were harvested during the late exponential growth phase. Cell-free extract was produced by passing the bacteria through a French pressure cell at $83 \mathrm{MPa}$ three times. Approximately $5 \mathrm{mg}$ DNAase 1 was added before the second passage. The extract was centrifuged at $5000 \mathrm{~g}$ for $30 \mathrm{~min}$ at $4{ }^{\circ} \mathrm{C}$ and the supernatant fraction was taken as the cell-free extract.

Protein assays. Protein assays were carried out using the Bradford (1976) method with bovine serum albumin as a standard. Detergentsolubilized proteins were assayed using bicinchoninic acid (BCA) protein assay reagent (Smith et al., 1985).

Enzyme assays. Nucleotide-dependent enzymes. The NAD(P)+dependent dehydrogenase enzymes were assayed fluorometrically in a filter instrument of the type described by Dalziel (1962). The assay contained $3.78 \mathrm{ml} 20 \mathrm{~mm}$-glycine $/ \mathrm{NaOH}$ buffer, pH 9.5, $20 \mu \mathrm{l}$ of enzyme preparation, $100 \mu \mathrm{l} 10 \mathrm{~mm}-\mathrm{NAD}(\mathrm{P})^{+}$and $20 \mu \mathrm{l} 10 \mathrm{~mm}-$ substrate dissolved in peroxide-free dioxan. The activity was measured at $25^{\circ} \mathrm{C}$ by following the increase in fluorescence as $\mathrm{NAD}(\mathrm{P}) \mathrm{H}$ was formed.

Nucleotide-independent enzymes. Alcohol and aldehyde dehydrogenase activities were determined by measuring the rate of 2,6dichlorophenolindophenol (DCPIP) reduction at $25^{\circ} \mathrm{C}$ and $600 \mathrm{~nm}$. The assay system contained $2.58 \mathrm{ml} 20 \mathrm{~mm}$-sodium phosphate buffer, pH 7.5, $100 \mu \mathrm{l}$ PMS ( $5 \mathrm{mg} \mathrm{ml}^{-1}$ ), $200 \mu \mathrm{l}$ DCPIP ( $\left.3 \mathrm{mM}\right), 20 \mu$ of enzyme solution and $100 \mu 10 \mathrm{~mm}$-substrate dissolved in peroxide-free dioxan.

The Würster's-Blue-dependent activity was assayed spectrophotometrically at $600 \mathrm{~nm}$. The assay system contained $2.79 \mathrm{ml} 20 \mathrm{~mm}-$ sodium phosphate buffer, $\mathrm{pH} 7 \cdot 5,10 \mu \mathrm{l}$ of enzyme preparation, $100 \mu \mathrm{l}$ Würster's Blue (0.6 $\mathrm{mg} \mathrm{ml}^{-1}$ ) (made up fresh daily) and $100 \mu 110 \mathrm{~mm}$ substrate dissolved in dioxan.

In general, assays were reproducible to within $\pm 5 \%$. In the kinetic studies assays were done in triplicate.

Preparation of Würster's Blue. This method is based on that of Michaelis \& Granick (1943), with minor alterations: tetramethyl$p$-phenylenediamine hydrochloride (TMPD) $(4 \mathrm{~g})$ was dissolved in a solution of $70 \mathrm{ml}$ water and $115 \mathrm{ml}$ methanol. Sodium perchlorate $(50 \mathrm{~g})$ was dissolved in this mixture followed by $127 \mathrm{ml}$ aqueous bromine solution ( $50 \%$ saturated), added dropwise. The mixture was then cooled to $-10^{\circ} \mathrm{C}$, filtered through Whatman no. 1 paper and washed several times with small portions of ice-cold methanol and then abundantly with dry diethyl ether. The dry, brown, metallic crystals were stored in a desiccator over $\mathrm{P}_{2} \mathrm{O}_{5}$ in the dark.

An operational extinction coefficient was determined for each batch of the dye. A known quantity of Würster's Blue was dissolved in water (at a concentration of about $0.6 \mathrm{mg} \mathrm{ml}^{-1}$ ) and $100 \mu \mathrm{l}$ of this was added to a cuvette containing $3.9 \mathrm{ml}$ of water. The absorbance was measured at $600 \mathrm{~nm}$ against water and the mixture was then completely reduced by adding a few grains of sodium dithionite. The molecular mass of Würster's Blue was taken as $263 \mathrm{Da}$ and the change in absorbance at $600 \mathrm{~nm}$ on the addition of dithionite was used to calculate the exact extinction coefficient (values of $\varepsilon$ of approximately $10000 \mathrm{M}^{-1} \mathrm{~cm}^{-1}$ were usually obtained)

Partial purification of $\mathrm{NADP}^{+}$-alcohol dehydrogenase. The crude cellfree extract (about $15 \mathrm{ml}, 6 \mathrm{mg} \mathrm{m}^{-1}$ ) was applied to a Sephacryl superfine S-300 column with a packed volume of $650 \mathrm{~cm}^{3}$ previously equilibrated with $50 \mathrm{~mm}$-HEPES/NaOH buffer, $\mathrm{pH} 7 \cdot 5$. The column was run at $4{ }^{\circ} \mathrm{C}$ with the equilibration buffer, at a flow rate of about
$3 \mathrm{ml} \mathrm{min}^{-1}$. The enzyme was eluted between 300 to $380 \mathrm{ml}$. The fractions with the highest specific activity were pooled and then applied to a Reactive Red A agarose column previously equilibrated with $50 \mathrm{~mm}$-HEPES/NaOH buffer, pH 7.5. The enzyme was selectively eluted from the column using $15 \mathrm{mM}^{-N_{A D P}+}$ in $200 \mathrm{mM}^{-}$ HEPES/NaOH buffer, pH 7.5. The eluate was dialysed overnight against $20 \mathrm{mM}$-HEPES/ $\mathrm{NaOH}$ buffer, $\mathrm{pH} 7.5$, to remove residual NADP+. The dialysis residue was then subjected to pressure filtration and the concentrated enzyme preparation could then be stored without loss of activity under liquid nitrogen.

Partial purification of $\mathrm{NADP}^{+}$-aldehyde dehdrogenase. The initial purification step is as for the alcohol dehydrogenase. Following application of the cell-free extract to the Sephacryl S-300 column the aldehyde dehydrogenase was found to be present in the cloudy fractions $(200$ to $300 \mathrm{ml})$ of the eluate. The fractions with the highest specific activity were pooled. Acetone $(90 \%, \mathrm{v} / \mathrm{v})$ cooled to $-20^{\circ} \mathrm{C}$ was added dropwise with constant stirring to the pooled enzyme preparation in a salt/ice bath, to give a final concentration of $30 \%(\mathrm{v} / \mathrm{v})$. The extract was immediately centrifuged at $4{ }^{\circ} \mathrm{C}$ for $20 \mathrm{~min}, 48000 \mathrm{~g}$. The pellet was resuspended in $20 \mathrm{mM}^{*}$ sodium phosphate buffer, $\mathrm{pH} 7.5$, with $1 \mathrm{mM}^{-}$ dithiothreitol and $1 \mathrm{~mm}$-EDTA. The resuspended pellet was again centrifuged to give a supernatant and pellet. The supernatant fraction was dialysed overnight against $20 \mathrm{~mm}$-sodium phosphate buffer, pH 7.5, 1 mm-DTT to remove residual acetone. The dialysis residue contained the partially purified enzyme.

Preparation of solubilized aldehyde dehydrogenase. The crude cell-free extract was centrifuged at $4{ }^{\circ} \mathrm{C}, 200000 \mathrm{~g}$ for $1.5 \mathrm{~h}$. The pellet was resuspended in $50 \mathrm{~mm}-\mathrm{HEPES} / \mathrm{NaOH}$ buffer, $\mathrm{pH} 7 \cdot 5$, containing $5 \%$ $(w / v)$ sucrose and centrifuged as before. The pellet from this centrifugation was resuspended to a protein concentration of 4 to $5 \mathrm{mg} \mathrm{ml}^{-1}$. Triton $\mathrm{X}-100(1 \%, \mathrm{v} / \mathrm{v})$ was added and the extract was stirred for $20 \mathrm{~min}$. The preparation was then centrifuged again as before and the supernatant contained the solubilized Würster's-Bluedependent aldehyde dehydrogenase.

Gas chromatography of alkanes and fatty acids. Fractions from the Sephacryl S-300 column $(5 \mathrm{ml})$ containing the aldehyde dehydrogenase were adjusted to $\mathrm{pH} 1$ with conc. $\mathrm{H}_{2} \mathrm{SO}_{4}$ and extracted three times with an equal volume of diethyl ether. The combined ether fractions were evaporated under nitrogen then dried under vacuum at $50{ }^{\circ} \mathrm{C}$ over $\mathrm{P}_{2} \mathrm{O}_{5}$. The residue was then methylated using trimethylsulphonium hydroxide (Butte, 1983) and analysed by gas chromatography.

A Phillips PU 4500 gas chromatograph, fitted with a flame ionization detector and integrator, was used to analyse the samples. The $10 \%(\mathrm{w} / \mathrm{w})$ diethylene glycol succinate column was set at $160{ }^{\circ} \mathrm{C}$ with the injector and detector ports set at $180^{\circ} \mathrm{C}$. The sample constituents were identified by running appropriate standards of alkanes, alcohols and fatty acid methyl esters. Each sample was re-run using a column temperature of $193{ }^{\circ} \mathrm{C}$ with the ports at $210^{\circ} \mathrm{C}$.

Molecular mass determination. Sephacryl superfine S-300 was

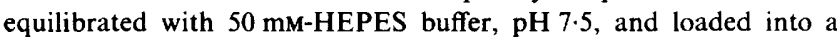
$1.4 \mathrm{~cm}$ diam. column. The column was attached to a LKB FPLC system and run at a flow rate of $0.8 \mathrm{ml} \mathrm{min}$. The packed height of the column was $89.5 \mathrm{~cm}$. The column was calibrated with cytochrome $c$ $(12400 \mathrm{Da})$, carbonic anhydrase $(29000 \mathrm{Da})$, bovine serum albumin $(66000 \mathrm{Da})$, yeast alcohol dehydrogenase $(150000 \mathrm{Da})$ and $\beta$-amylase (200000 Da).

Polyacrylamide gel electrophoresis. A non-denaturing gel was run according to the method of Hames (1981). A discontinuous buffer system was used in a mini-gel apparatus and the concentration of acrylamide in the resolving gel was $10 \%(w / v)$. The sample of cell-free extract was diluted $50 \%$ in the sample preparation mixture and $15 \mu \mathrm{l}$ was applied to each sample well. The gel was run at $4^{\circ} \mathrm{C}, 80 \mathrm{~V}$ (constant 
Table 1. Total activities and specific activities of alcohol and aldehyde dehydrogenases in Acinetobacter calcoaceticus HOI-N grown on various carbon sources

The enzymes were assayed in the crude cell-free extract according to the conditions stated in Methods using, respectively decanol and decanal as substrates. Assays were done in duplicate and were reproducible to within $\pm 5 \%$; mean values are recorded. TA, total activity $\left(\mu \mathrm{mol} \mathrm{min} \mathrm{min}^{-1}\right.$ in $3 \mathrm{~g}$ wet wt cells); SA, specific activity [nmol $\mathrm{min}^{-1}$ $(\mathrm{mg} \text { protein })^{-1}$.

\begin{tabular}{|c|c|c|c|c|c|c|c|c|c|c|}
\hline \multirow{4}{*}{$\begin{array}{l}\text { Growth } \\
\text { substrate }\end{array}$} & \multicolumn{10}{|c|}{ Enzymes and cofactors: } \\
\hline & \multicolumn{4}{|c|}{ Alcohol dehydrogenase } & \multicolumn{6}{|c|}{ Aldehyde dehydrogenase } \\
\hline & \multicolumn{2}{|c|}{$\mathrm{NAD}^{+}$} & \multicolumn{2}{|c|}{ NADP+ } & \multicolumn{2}{|c|}{$\mathrm{NAD}^{+}$} & \multicolumn{2}{|c|}{ NADP +} & \multicolumn{2}{|c|}{ Würster's Blue } \\
\hline & TA & SA & TA & $\mathrm{SA}$ & TA & SA & TA & SA & TA & SA \\
\hline Hexadecane & $2 \cdot 3$ & 26 & 22 & 250 & $3 \cdot 4$ & 39 & 20 & 230 & 170 & 1940 \\
\hline Hexadecanol & 3.9 & 35 & 22 & 200 & 3.9 & 36 & 26 & 240 & 140 & 1300 \\
\hline Sodium succinate & 1.8 & $10 \cdot 5$ & 22 & 130 & $2 \cdot 7$ & 17 & $1 \cdot 0$ & 6 & 40 & 380 \\
\hline Sodium acetate & $2 \cdot 0$ & 20 & 21 & 210 & $2 \cdot 8$ & 28 & 1.7 & 17 & 30 & 740 \\
\hline
\end{tabular}

voltage) until the front was $1 \mathrm{~cm}$ from the base of the gel. The gel was cut and stained for activity. The activity stain contained $40 \mathrm{ml} 20 \mathrm{mM}$ sodium phosphate buffer, pH 8.0, $2 \mathrm{mg}$ PMS, $8 \mathrm{mg}$ Nitroblue tetrazolium and $2 \mathrm{ml} 10 \mathrm{~mm}$-substrate in dioxan. The nucleotidedependent dehydrogenases required the presence of $\mathrm{NAD}(\mathrm{P})^{+}(10 \mathrm{ml}$, $10 \mathrm{mM}$ ). The gel was soaked in the activity stain for $30 \mathrm{~min}$ at $30^{\circ} \mathrm{C}$ in the dark, after which time the activity bands were visible. The gel could later be stained for protein using the one-step Coomassie Blue stain (Zehr et al., 1989).

Materials. Yeast extract, nutrient agar and nutrient broth were from Oxoid. Hexadecane, alcohols, aldehydes, Nitroblue tetrazolium, PMS, TMPD, DCPIP, DNAase, bovine serum albumin, Reactive Red A agarose, Sephacryl S-300 and the molecular mass markers for gel filtration were from Sigma. BCA protein reagent, Triton X-100 $(10 \%$, $v / v$, peroxide-free $)$ and $B r i j-35(10 \%, v / v$, peroxide-free) were from Pierce and Warriner, Chester, UK. NAD ${ }^{+}$was from Park Scientific, Northampton, UK. Dithiothreitol was from Boehringer Mannheim.

\section{Results}

Acinetobacter calcoaceticus strain $\mathrm{HO} 1-\mathrm{N}$ was grown on a variety of carbon sources and the crude cell-free extract from each batch of cells was assayed for long-chain alcohol and aldehyde dehydrogenase activity according to the conditions in Methods. NAD ${ }^{+}$- and NADP+dependent alcohol and aldehyde dehydrogenase activities were found as expected (Table 1). In addition, a third and very active aldehyde dehydrogenase was found. This enzyme was nucleotide independent and was capable of utilizing the artificial electron acceptors Würster's Blue and PMS.

Apart from the NADP+-dependent aldehyde dehydrogenase the total activities (Table 1) of the $\mathrm{NAD}^{+-}$and $\mathrm{NADP}^{+}$-dependent enzymes do not appear to depend on the choice of carbon source. The $\mathrm{NAD}^{+}$-dependent alcohol dehydrogenase activity is low and represents only about $10 \%$ of the total alcohol oxidizing activity of the cell. It is noteworthy that no nucleotide-independent alcohol dehydrogenase was found in the cell-free extract.

The NAD ${ }^{+}$-dependent aldehyde dehydrogenase is constitutive whilst both the NADP+ ${ }^{+}$and the Würster'sBlue-dependent aldehyde dehydrogenases are induced during growth of the bacterium on the long-chain carbon sources. When induced, the Würster's-Blue-dependent enzyme represents approximately $80 \%$ of the aldehyde oxidizing activity present. However, the NADP+dependent enzyme is induced 20 -fold by the long-chain carbon sources and to a far greater extent than the Würster's-Blue-dependent enzyme which is only induced 4-fold. This disparity suggests that the $\mathrm{NADP}^{+}$-dependent aldehyde dehydrogenase may be more intimately associated with alkane metabolism than the nucleotideindependent enzyme.

\section{Alcohol dehydrogenase enzymes}

It seemed important to know whether the nucleotidedependent alcohol dehydrogenase activities are carried on the same or different proteins as, for example, liver alcohol dehydrogenase shows some activity towards $\mathrm{NADP}^{+}$even though it is more active with $\mathrm{NAD}^{+}$ (Dalziel \& Dickinson, 1965). To this end, thermal stability studies of the $\mathrm{NAD}^{+}$- and $\mathrm{NADP}^{+}$-dependent alcohol dehydrogenases in crude extracts were performed. Fig. 1 shows the results obtained at $60^{\circ} \mathrm{C}$. The traces confirm the presence of distinct $\mathrm{NAD}^{+}$- and $\mathrm{NADP}^{+}$-dependent activities. The $\mathrm{NADP}^{+}$-dependent activity trace shows a biphasic pattern: within 5 min almost $40 \%$ of activity was lost and then over the following $90 \mathrm{~min}$ there was a further reduction of only $30 \%$. The $\mathrm{NAD}^{+}$-dependent enzyme, on the other hand, lost $75 \%$ of activity within $15 \mathrm{~min}$ but then remained 


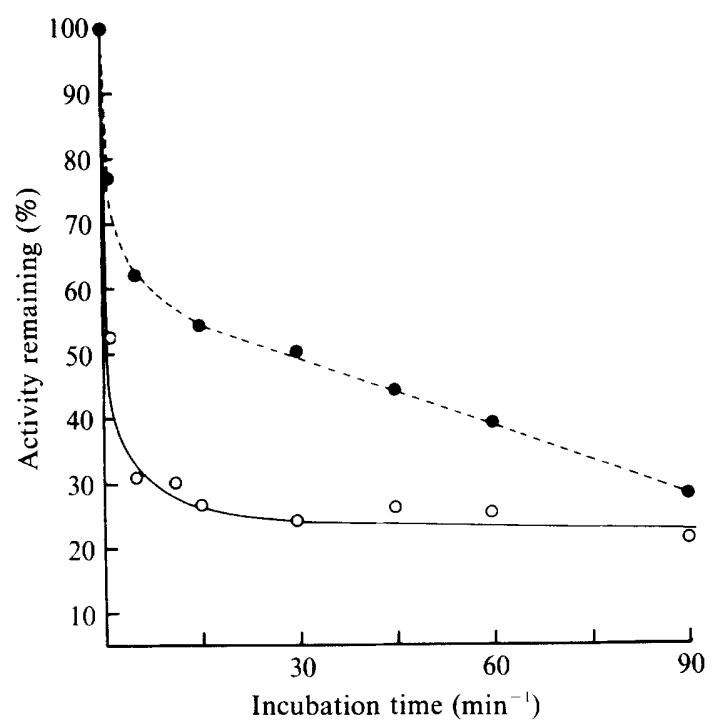

Fig. 1. Temperature stability of the alcohol dehydrogenases at $60^{\circ} \mathrm{C}$ : ○, NAD-dependent; $\bullet$, NADP-dependent.

almost constant over the remaining $75 \mathrm{~min}$. Apart from demonstrating that the $\mathrm{NAD}^{+}$and $\mathrm{NADP}^{+}$activities reside on different proteins, the biphasic character of the stability traces suggests that there may well be two distinct forms of both the $\mathrm{NAD}^{+}$-linked and NADP+linked enzymes. In the case of the $\mathrm{NADP}^{+}$-linked enzymes, this seems to be supported by other evidence (see below). However, as the thermal stability results were obtained using crude cell extracts one should exercise caution in interpreting them.

Following centrifugation of the cell-free extract at $200000 \mathrm{~g}$ for $1.5 \mathrm{~h}$, the long-chain alcohol oxidizing activity was found entirely in the supernatant and, therefore, in the soluble fraction. The existence of separate $\mathrm{NAD}^{+}$- and $\mathrm{NADP}^{+}$-dependent alcohol dehydrogenases was confirmed by running a non-denaturing polyacrylamide gel using cell-free extract. The gel was cut longitudinally and the duplicate sample tracks were stained for activity in the presence of either NAD ${ }^{+}$ or NADP+. The gel (Fig. 2) shows that the NAD ${ }^{+}$ dependent activity $\left(R_{F}=0.09\right)$ is distinct from either of the NADP ${ }^{+}$-dependent alcohol dehydrogenases $\left(R_{F}=\right.$ $\left.0.315, R_{F}=0.635\right)$. If there are two $\mathrm{NAD}^{+}$-linked activities (see above) then they are not separated by this experiment. As the $\mathrm{NAD}^{+}$-dependent alcohol dehydrogenase represents only 10 to $15 \%$ of the alcohol oxidizing activity within the cell (Table 1) and, as this activity is also very low in absolute terms, this enzyme was not studied further.

A partial purification procedure was established for one of the NADP ${ }^{+}$-dependent enzymes (see Table $2 a$ ). Following fractionation of the cell-free extract by

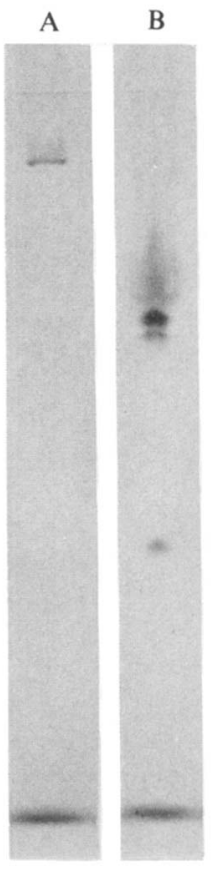

Fig. 2. Non-denaturing $10 \%$ polyacrylamide gel stained for $\mathrm{NAD}(\mathrm{P})^{+}$dependent alcohol dehydrogenases. Lane $\mathrm{A}$, single band $\left(R_{F}=0.09\right)$ of NAD ${ }^{+}$-dependent alcohol dehydrogenase; lane $B$, two bands $\left(R_{F}=0.315\right.$ and 0.635$)$ of $\mathrm{NADP}^{+}$-dependent alcohol dehydrogenases.

Table 2. Specific activity and percentage total units during the purification of the $N A D P^{+}$-dependent alcohol and aldehyde dehydrogenases

Assays were done in duplicate and were reproducible to within $\pm 5 \%$; mean values are recorded.

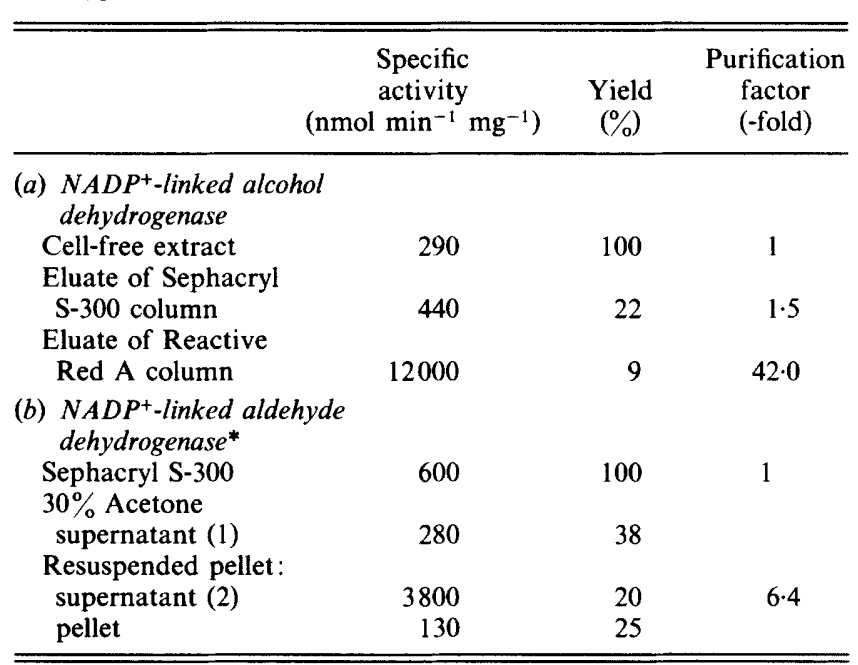

* The active fractions from the Sephacryl S-300 column were pooled and precipitated with $30 \%(\mathrm{v} / \mathrm{v})$ acetone. The pellet was then resuspended to give supernatant (2) containing the partially purified enzyme.

n-Aldehyde chain length

passage down the Sephacryl S-300 column, a nondenaturing polyacrylamide gel was run using the pooled 
fractions containing the $\mathrm{NADP}^{+}$-dependent activity. When stained for activity only one band was visible and this had an $R_{F}=0.314$, which corresponds to one of those shown in Fig. 2, lane B. This preparation of the enzyme was subjected to heat inactivation at $60^{\circ} \mathrm{C}$. In this case, the biphasic pattern seen previously for the NADP ${ }^{+}$. dependent alcohol dehydrogenase activity was not apparent. Instead, the enzyme lost $30 \%$ of its activity over $90 \mathrm{~min}$. Thus only the more stable of the two $\mathrm{NADP}^{+}$-dependent alcohol dehydrogenases remained after the Sephacryl S-300 step. The fate of the less stable enzyme was not investigated.

The enzyme recovered from the Sephacryl S-300 step was further purified by chromatography on Reactive Red A agarose as a preliminary to a detailed substrate specificity study. The equilibrium constant of the purified enzyme was also measured at $\mathrm{pH} 7 \cdot 0$ and $\mathrm{pH} 8 \cdot 0$ using decanol as the alcohol substrate. The measured values were $K_{\text {eq,app }}=1.01 \times 10^{-4}$ at $\mathrm{pH} 7.0$ and $7 \cdot 27 \times 10^{-4}$ at $\mathrm{pH} 8 \cdot 0$. These values indicate a value for the $\mathrm{pH}$-independent equilibrium constant of $K_{\mathrm{eq}}=$ $8.8 \times 10^{-12} \mathrm{M}$. This is very close to the estimate $\left(1.1 \times 10^{-11} \mathrm{M}\right)$ for the ethanol-acetaldehyde system catalysed by horse liver alcohol dehydrogenase (Bäcklin, 1958). The determination of the equilibrium constant shows that our $\mathrm{NADP}^{+}$-linked alcohol oxidation is a conventional alcohol dehydrogenase reaction and is not, for example, the result of the combined activity of an alcohol oxidase and an aldehyde dehydrogenase. Such a system is found in extracts of the yeast Candida tropicalis when grown on alkanes and it was some years before its true nature was established (Kemp et al., 1988). It is important to note that no alcohol oxidase activity was detected in cell-free extracts of alkane-grown Acinetobacter.

The pI of the purified alcohol dehydrogenase was found to be 4.5 in an iso-electric focusing experiment. The molecular mass of the native enzyme was measured by gel filtration on a calibrated column of Sephacryl S-300 superfine. Comparison with authentic standards indicated a molecular mass of $144000 \pm 5000 \mathrm{Da}$.

The $K_{\mathrm{m}}$ and $V_{\max }$ values of the $\mathrm{NADP}^{+}$-dependent enzyme were measured with a range of substrates varying in chain length from $\mathrm{C}_{4}$ to $\mathrm{C}_{14}$ (Table 3). The apparent $K_{\mathrm{m}}$ values of the $\mathrm{NADP}^{+}$-dependent alcohol dehydrogenase decreased dramatically with increasing chain length down to $5.2 \mu \mathrm{M}$ for the $\mathrm{C}_{14}$ substrate. The $V_{\max }$ values also decreased with increasing chain length. In contrast to the results with other substrates, the Lineweaver-Burk plot for butan-1-ol displayed a curved line as shown in Fig. 3 and it was not possible to measure the $K_{\mathrm{m}}$ accurately. The curved pattern displayed by the enzyme with the $C_{4}$ substrate is not due to the range of substrate concentration as the $\mathrm{C}_{8}$ measurements were

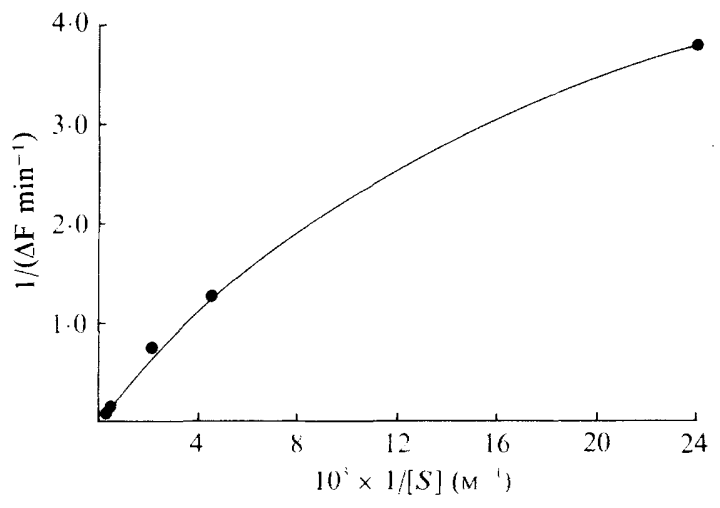

Fig. 3. Lineweaver-Burk plot for the $\mathrm{NADP}^{+}$-dependent alcohol dehydrogenase using the $\mathrm{C}_{4}$ substrate. The expected linear plot is not found with this substrate.

Table 3. Apparent $K_{\mathrm{m}}$ and $V_{\max }$ values for the alcohols used by the $N A D P^{+}$-dependent alcohol dehydrogenase

The $\mathrm{NADP}^{+}$concentration was $0.25 \mathrm{~mm}$. Estimates of the kinetic coefficients were generally reproducible to within $\pm 15 \%$.

\begin{tabular}{lcc}
\hline \hline $\mathrm{n}$-Alcohol & $K_{\mathrm{m}}(\mu \mathrm{M})$ & $V_{\max }^{\prime}\left(\mu \mathrm{mol} \mathrm{min}^{-1} \mathrm{mg}^{-1}\right)$ \\
\hline $\mathrm{C}_{4}$ & $>300$ & \\
$\mathrm{C}_{6}$ & 290 & 31.5 \\
$\mathrm{C}_{8}$ & 120 & 42.0 \\
$\mathrm{C}_{10}$ & $32 \cdot 3$ & $19 \cdot 4$ \\
$\mathrm{C}_{12}$ & $4 \cdot 6$ & 6.5 \\
$\mathrm{C}_{14}$ & $5 \cdot 2$ & $1 \cdot 4$ \\
\hline \hline
\end{tabular}

made over a more extended range than that used for $\mathrm{C}_{4}$ and the usual linear pattern was obtained.

\section{Nucleotide-dependent aldehyde dehydrogenase enzymes}

As with the alcohol dehydrogenase activities, both $\mathrm{NAD}^{+}$- and $\mathrm{NADP}^{+}$-dependent aldehyde dehydrogenase enzymes were present in the crude cell-free extract. The inducibility of the $\mathrm{NADP}^{+}$-dependent enzyme in bacteria growing on long-chain carbon sources showed that it was a separate enzyme to that utilizing $\mathrm{NAD}^{+}$as a cofactor. This was confirmed when the partially purified $\mathrm{NADP}^{+}$-dependent aldehyde dehydrogenase did not utilize $\mathrm{NAD}^{+}$. The $\mathrm{NADP}^{+}$-dependent enzyme represents approximately $85 \%$ of the nucleotide-dependent aldehyde oxidizing activity in extracts of cells grown on hexadecane or hexadecanol. Both the $\mathrm{NAD}^{+-}$and $\mathrm{NADP}^{+}$-dependent aldehyde dehydrogenase enzymes were present in the supernatant following a $200000 \mathrm{~g}$ centrifugation of the crude cell-free extract for $1.5 \mathrm{~h}$.

Purification of the inducible $\mathrm{NADP}^{+}$-dependent enzyme was attempted. When the crude cell-free extract 
was applied to a Sephacryl S-300 gel filtration column, the enzyme was eluted in the void volume of the column with a 4-fold purification (Table $2 b$ ). The fractions were milky in appearance. This behaviour suggested that either the enzyme is of very large molecular mass $\left(>10^{6} \mathrm{Da}\right)$ and this seems rather unlikely or that it is associated with the cloudy material. A. calcoaceticus strain HOl-N accumulates hydrocarbon in intracellular vesicles during growth on hexadecane (Scott \& Finnerty, 1976) and it appeared that the $\mathrm{NADP}^{+}$-dependent aldehyde dehydrogenase could well be associated with them. The fractions from the column, containing the highest enzyme activity were extracted with diethyl ether (a procedure which totally inactivated the enzyme) and the extract was analysed by gas chromatography to try to establish the nature of the material with which the enzyme was associated. The residue was found to consist of hexadecane (the growth substrate, $66 \%$ ) and palmitic (16:0) and palmitoleic (16:1) acids (13\% and 9\%, respectively). This analysis seems to show that considerable monoterminal oxidation of hexadecane is taking place.

Various attempts were made to disrupt the association between enzyme and hydrocarbon and preserve enzyme activity. The enzyme would not bind to Reactive Red A agarose which has an affinity for $\mathrm{NADP}^{+}$-dependent enzymes. The effects of different solvents $\left(C_{2}\right.$ to $C_{8}$ alcohols, acetone) and detergents (Triton $\mathrm{X}-100$ and Brij-35) were investigated. The detergents were added to the extract to give a final concentration of $2 \%(\mathrm{v} / \mathrm{v})$ and $5 \%(\mathrm{v} / \mathrm{v})$. These treatments appeared to be too harsh with recoveries of only 25 and $10 \%$ of the original activity immediately following addition of the detergent. The use of the alcohols as solvents also resulted in losses of activity with no purification. Treatment of the extract with $30 \%(\mathrm{v} / \mathrm{v})$ acetone appeared to be the best method for removing the hydrocarbon. This result is included in Table 2(b). It should be noted that there is still a very substantial amount of activity remaining in the final pellet. This activity could not be recovered with the use of detergents. For example, addition of $0.1 \%$ Triton $\mathrm{X}-100$ to the pellet resulted in an immediate loss of $80 \%$ of the activity.

It seems likely that the inducible $\mathrm{NADP}^{+}$-dependent aldehyde dehydrogenase is present in the cell in association with the intracellular vesicles of hydrocarbon and that it is stabilized by this association. Supernatant (2) (Table 2), resulting from the acetone treatment has an opalescent appearance implying that the enzyme present is still in association with some hydrocarbon. Clearly more work is needed to resolve this problem.

Apparent $K_{\mathrm{m}}$ and $V_{\max }$ values for the purified preparation of the enzyme were measured for the various chain-length substrates (Table 4). It is clear that at very low substrate concentrations the enzyme is much more
Table 4. Apparent $K_{\mathrm{m}}$ and $V_{\max }$ values for the NADP+dependent aldehyde dehydrogenase with various chain-length substrates

The NADP ${ }^{+}$concentration was $0.25 \mathrm{~mm}$. Estimates of the kinetic coefficients were generally reproducible to within $\pm 15 \%$.

\begin{tabular}{|c|c|c|}
\hline n-Aldehyde & $K_{\mathrm{m}}$ & 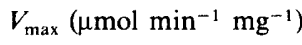 \\
\hline $\mathrm{C}_{4}$ & $3.6 \mathrm{mM}$ & $2 \cdot 1$ \\
\hline $\mathrm{C}_{6}^{4}$ & $0.4 \mathrm{mM}$ & $1 \cdot 2$ \\
\hline $\mathrm{C}_{8}$ & $2 \cdot 1 \mu \mathrm{M}$ & $1 \cdot 4$ \\
\hline $\mathrm{C}_{10}$ & $0.2 \mu \mathrm{M}$ & $2 \cdot 3$ \\
\hline $\mathrm{C}_{12}$ & & $>1 \cdot 2$ \\
\hline $\mathrm{C}_{14}$ & & $>1 \cdot 4$ \\
\hline
\end{tabular}

effective with decanal than butanal or hexanal. This might be expected for an enzyme induced by growth on long-chain hydrocarbons. One interesting feature is that the apparent $V_{\max }$ appears to be independent of the chain length of the substrate even though the apparent $K_{\mathrm{m}}$ varies by several thousandfold. This is in contrast to the $V_{\max }$ values for the $\mathrm{NADP}^{+}$-dependent alcohol dehydrogenase which vary with the chain length of the substrate (Table 3). Although it is necessary to be cautious, since a complete kinetic analysis was not attempted, it seems likely that the rate-limiting step in the aldehyde dehydrogenase reaction may well be the release of NADPH from the terminal enzyme-NADPH complex. A compulsory order mechanism having this feature has been well established for mammalian liver aldehyde dehydrogenase (Hart \& Dickinson, 1982, MacGibbon et al., 1977).

With the long-chain substrates (dodecanal and tetradecanal) serious problems with substrate inhibition were encountered. This is illustrated in Fig. 4. Whereas decanal shows an essentially normal hyperbolic curve with perhaps a small degree of inhibition at the highest concentrations, dodecanal shows marked inhibition at all accessible concentrations. Even at the lowest concentration used $(0.3 \mu \mathrm{M})$ the measured rate was still increasing. This behaviour presents insuperable problems to kinetic analysis. Apparent $V_{\max }$ estimates were made from the rates measured at the lowest concentration we could use. Clearly these will be minimum estimates. $K_{\mathrm{m}}$ values must be presumed to be much lower than our lowest substrate concentration.

At the concentration at which decanal was shown to be the best substrate $(50 \mu \mathrm{M})$, butanal and hexanal were present at concentrations below their $K_{\mathrm{m}}$ values, whilst with dodecanal and tetradecanal these concentrations were very strongly inhibitory. Thus, the apparent specificity of the enzyme is dependent on the conditions chosen to investigate it (see Fig. 5). At very low concentrations (nM) the enzyme shows a strong preference for long-chain substrates but at higher concentra- 


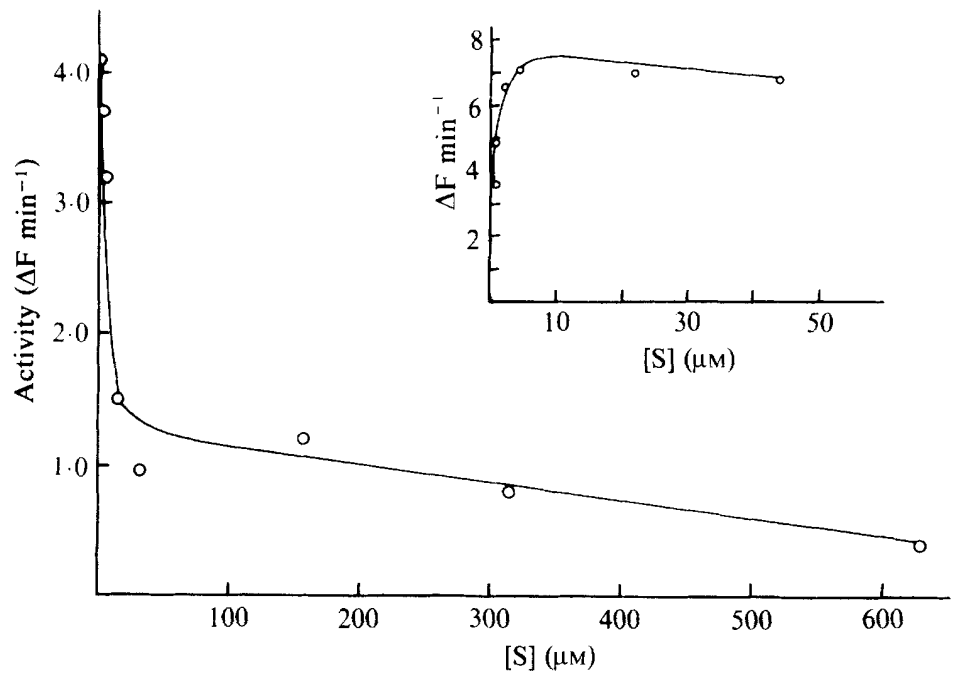

Fig. 4

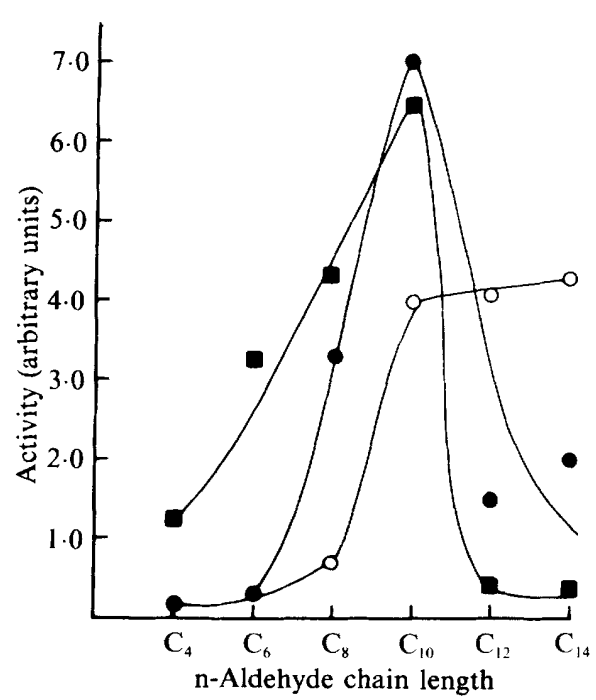

Fig. 5

Fig. 4. Activity vs substrate concentration for the $\mathrm{NADP}^{+}$-dependent aldehyde dehydrogenase using the $\mathrm{C}_{12}$ substrate. The substrate was inhibitory at very low concentrations. Inset, expected pattern of activity vs substrate concentration for decanal.

Fig. 5. Substrate specificity pattern for the $\mathrm{NADP}^{+}$-dependent aldehyde dehydrogenase measured with various concentrations of substrates: $O, 0.3 \mu \mathrm{M} ; \bullet, 15 \mu \mathrm{M} ; \mathbf{\square}, 1 \mathrm{mM}$.

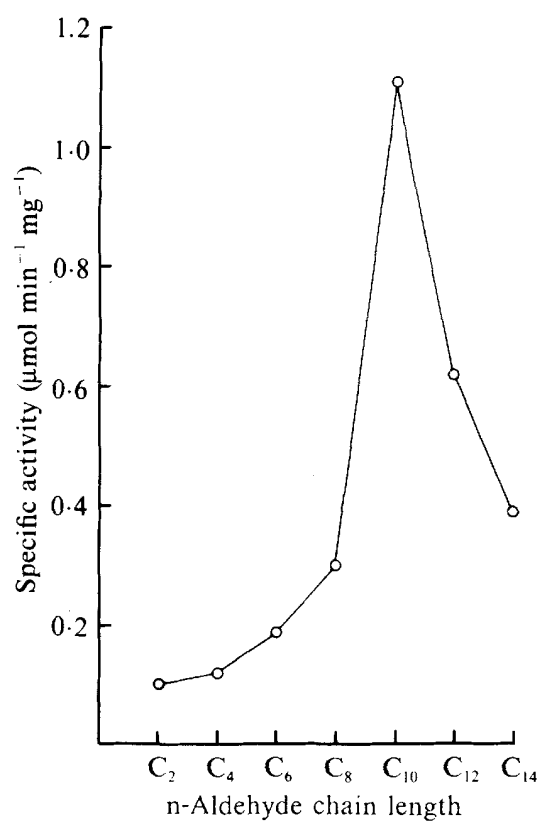

Fig. 6

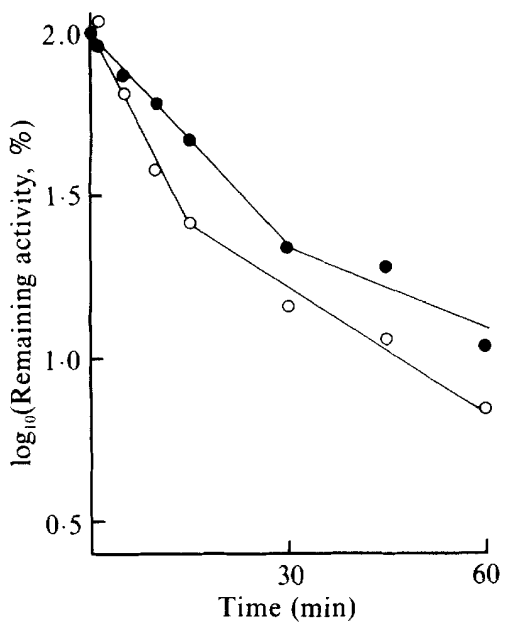

Fig. 7

Fig. 6. Substrate specificity pattern for the Würster's-Blue-dependent aldehyde dehydrogenase measured in cell-free extract over a range of $n$-aldehydes.

Fig. 7. Semi-log plot of percentage activity of the Würster's-Blue-dependent aldehyde dehydrogenase remaining over an incubation period of $1 \mathrm{~h} . \quad-55^{\circ} \mathrm{C} ; \mathrm{O}, 60^{\circ} \mathrm{C}$.

tions (mM) the preference shifts towards the mid chainlength aldehydes.

\section{Nucleotide-independent aldehyde dehydrogenase}

This enzyme, when induced, represents the bulk $(80 \%)$ of the aldehyde oxidizing activity within the cell (see Table
1). The presence of this enzyme, which oxidizes longchain aldehydes at the expense of the electron acceptors PMS/DCPIP and Würster's Blue, has not been reported previously in the genus Acinetobacter. DCPIP only functions as an electron-acceptor if PMS is also present. The PMS/DCPIP assay was not used in routine work with crude cell extracts because of the presence of a 
membrane-bound NADH oxidase which affected the reduction of DCPIP.

The enzyme is found in the membrane fraction following a $200000 \mathrm{~g}$ centrifugation for $1.5 \mathrm{~h}$ at $4{ }^{\circ} \mathrm{C}$. It could be solubilized ( $70 \%$ yield) in a $30 \mathrm{~min}$ incubation at $4{ }^{\circ} \mathrm{C}$ by using $1.0 \%$ Triton $\mathrm{X}-100$; other detergents (e.g. CHAPS, Brij-35, sodium cholate) were not as effective. More extended periods of extraction gave very little improvement. After $17 \mathrm{~h}$ in Triton X-100 $75 \%$ of the enzyme was solubilized.

The substrate specificity of the enzyme in solubilized extracts was studied using $C_{2}$ to $C_{14} n$-aldehydes. Fig. 6 shows that the enzyme is most active against decanal. It is noteworthy that the enzyme activity found in succinate- or acetate-grown cells also acts most effectively on the $\mathrm{C}_{10}$ substrate. Of course, in this case the specific activity of the enzyme is only $25 \%$ of that seen in induced cells.

The temperature stability profile was studied at 55 and $60^{\circ} \mathrm{C}$. Fig. 7 shows first-order plots of the decline in activity. At both temperatures a biphasic pattern of activity loss was seen and the half-life of the remaining activity increased about threefold over a $20 \mathrm{~min}$ incubation. The reason for this is not known, but it seems that all the enzyme molecules in this crude extract may not be the same or that the the denaturation process involves the generation of less active, but more stable species.

\section{Discussion}

Singer \& Finnerty $(1985 b)$ reported the presence of three alcohol dehydrogenases in the same bacterium as has been studied here. ADH-A was induced by growth of the cells on ethanol and was essentially an $\mathrm{NAD}^{+}$-linked ethanol dehydrogenase. We do not find this enzyme under our growth conditions. Their other alcohol dehydrogenases had mid- to long-chain specificity: ADH-B was constitutive, NADP ${ }^{+}$-dependent and functioned optimally with octanol as substrate; $\mathrm{HDH}$ was an $\mathrm{NAD}^{+}$-dependent hexadecanol dehydrogenase induced 5 - to 11 -fold by growing the bacterium on hexadecane or hexadecanol. Despite our repeated attempts, and using a range of potential cofactors and electron acceptors $\left(\mathrm{NAD}^{+}, \mathrm{NADP}^{+}, \mathrm{PMS} / \mathrm{DCPIP}, \mathrm{Würster}\right.$ 's Blue), no inducible alcohol dehydrogenase/oxidase was detected in the cells grown on hydrocarbons. Clearly, our findings are quite different from those of Singer \& Finnerty (1985b). Jirausch et al. (1986), however, have described an inducible DCPIP-utilizing alcohol dehydrogenase with an activity maximally only $20 \%$ of the activity of an $\mathrm{NADP}^{+}$-dependent enzyme, which itself, as will be seen below, is present at much lower activities than we describe.
The NAD ${ }^{+}$-dependent alcohol dehydrogenase found here showed a preference for decanol while the partially purified $\mathrm{NADP}^{+}$-dependent enzyme showed a low apparent $K_{\mathrm{m}}$ of $5 \cdot 2 \mu \mathrm{M}$ for tetradecanol. Jirausch et al. (1986) found a constitutive $\mathrm{NADP}^{+}$-linked alcohol dehydrogenase in a different strain of $A$. calcoaceticus which had activity with alkan-1-ols up to decanol. Oxidation of longer-chain alcohols was not examined but presumably would have occurred.

The partially purified $\mathrm{NADP}^{+}$-dependent alcohol dehydrogenase studied here seems to be equivalent to that reported by Jirausch et al. (1986) in being constitutive and soluble. However, the level of activity that we find in crude extracts is some 17 -fold greater than found by these authors. Our $\mathrm{NAD}^{+}$-linked enzyme may appear to be the HDH reported by Singer \& Finnerty $(1985 \mathrm{~b})$ but, while our enzyme is not induced, it is present in much greater amounts (up to 8-fold). The combined activities of $\mathrm{NAD}^{+}$- and NADP+-linked alcohol dehydrogenases that we find are 100-fold greater than those described by Singer \& Finnerty (1985b).

The occurrence of such a range of alcohol dehydrogenases indicates that it would be very difficult to produce mutants of $\boldsymbol{A}$. calcoaceticus which accumulate alkanols when growing on $\mathrm{n}$-alkanes. It would be difficult to delete all the enzymes simultaneously.

In turning to the aldehyde dehydrogenase of this organism, the presence of the Würster's-Blue-dependent enzyme is completely novel in this genus. Nucleotideindependent aldehyde dehydrogenases have previously been reported in Acetobacter spp. (Ameyama et al., 1981; Hommel \& Kleber, 1990; Fukaya et al., 1989), a Pseudomonas sp. (Poels et al., 1987) a Gluconobacter sp. (Adachi et al., 1978) and in Hyphomicrobium X (Marison \& Attwood, 1980). The enzyme described here differs from those previously reported in being induced on longchain carbon sources and having a specificity for longchain substrates. Kleber et al. (1983) reported only an $\mathrm{NADP}^{+}$-dependent, inducible aldehyde dehydrogenase in Acinetobacter but could have missed the $\mathrm{NAD}^{+-}$ dependent enzyme because of its very low activity. (By using a fluorimetric assay we were able to monitor activities much lower than can be detected by the more conventional spectrophotometric method.)

The strong induction of long-chain aldehyde oxidizing activity by growth of the bacterium on n-alkanes suggests that the aldehydes must be significant metabolites under these conditions. The lack of a corresponding increase in long-chain alcohol oxidizing activity seems to be significant but Table 1 shows that even after induction of the NADP+-linked aldehyde dehydrogenase the $\mathrm{NAD}^{+}$and NADP+-linked alcohol and aldehyde dehydrogenase activities are similar. The results here do not seem to help decide whether a pathway of mono-terminal 
oxidation (see route 1, Introduction) or the alternative involving hydroperoxides and per-acids (route 2) (Finnerty, 1977, 1988) is operational in n-alkane oxidation. The fact that the two aldehyde dehydrogenases are associated with different cell fractions (i.e. hydrocarbon vesicles and microsomal membranes) suggest separate roles for the two enzymes and separate destinations for the products. Whether one of these is $\beta$-oxidation and the other wax ester synthesis (Fixter et al., 1986) remains to be established.

The Würster's-Blue-dependent enzyme presumably functions with some as yet unknown and probably membrane-associated electron acceptor. The action of this enzyme could perhaps allow oxidation of aldehydes without affecting [NAD $\left.{ }^{+}\right] /[\mathrm{NADH}]$ or $\left[\mathrm{NADP}^{+}\right] /$ [NADPH] ratios in the cell. However, a full appreciation of the significance of the Würster's-Blue-dependent enzyme requires a knowledge of its natural electron acceptor and its activity with that acceptor. So far that information is not available.

This work was funded by the European Community Biotechnology Action Programme (Grant no. 02100). We would like to thank Dr F. Meussdoerffer and Dr M. Bahn of Henkel KGaA, Dusseldorf, for their support and helpful discussion.

\section{References}

Adachi, O., Tayama, K., Shinagawa, E., Matsushita, K. \& Ameyama, M. (1980). Purification and characterization of membrane-bound aldehyde dehydrogenase from Gluconobacter suboxydans. Agricultural and Biological Chemistry 44, 503-515.

ameyama, M., Osada, K., Shinayawa, E., Matsushita, K. \& Adachi, O. (1981). Purification and characterization of aldehyde dehydrogenase of Acetobacter aceti. Agricultural and Biological Chemistry 45, $1889-1890$.

BÄCKLIN, K. I. (1958). The equilibrium constant of the system ethanol, aldehyde, DPN ${ }^{+}, \mathrm{DPNH}$ and $\mathrm{H}^{+}$. Acta Chemica Scandinavica 12 , 1279-1285.

Benso:v, S. \& SHAPIRO, J. (1976). Plasmid-determined alcohol dehydrogenase activity in alkane-utilizing strains of $P$. putida. Journal of Bacteriology 126, 794-798.

BRADFORD, M. M. (1976). A rapid and sensitive method for the quantitation of microgram quantities of protein utilizing the principle of protein-dye binding. Analytical Biochemistry 72, 248-254.

BUTTE, W. (1983). Rapid method for the determination of fatty acid profiles from fats and oils using trimethylsulphonium hydroxide for transesterification. Journal of Chromatography 261, 142-145.

Dalziel, K. (1962). Kinetic studies of liver alcohol dehydrogenase. Biochemical Journal 84, 244-254.

Dalziel, K. \& Dickinson, F. M. (1965). The activity of liver alcohol dehydrogenase with nicotinamide adenine dinucleotide phosphate as co-enzyme. Biochemical Journal 95, 311-320.

FINNERTY, W. R. (1977). The biochemistry of microbial alkane oxidation: new insights and perspectives. Trends in Biochemical Sciences 2, 73-75.

FINNERTY, W. R. (1988). Lipids of Acinetobacter. In Proceedings of the World Conference on Biotechnology for the Fats and Oils Industry, pp. 184-188. Edited by T. H. Applewhite. Champaign, Illinois: American Oil Chemists' Society.
Finnerty, W. R., Kallio, R. E., Klimstra, P. D. \& Wawzonez, S. (1962). Utilization of l-alkyl hydroperoxides by Micrococcus cerificans. Zeitschrift für allgemeine Mikrobiologie 2, 263-266.

Fixter, L. M., Nagi, M. N., McCormack, J. G. \& Fewson, C. A. (1986). Structure, distribution and function of wax esters in Acinetobacter calcoaceticus. Journal of General Microbiology 132, 3147-3157.

Fukaya, M., Tayama, K., Okumura, N., Kawamura, Y. \& Beppu, T. (1989). Purification and characterization of membrane-bound aldehyde dehydrogenase from Acetobacter polyoxogenes sp. nov. Applied Microbiology and Biotechnology 32, 176-180.

Hames, B. D. (1981). An introduction to polyacrylamide gel electrophoresis. In Gel Electrophoresis of Proteins, a Practical Approach, pp. 1-86. Edited by B. D. Hames \& D. Rickwood. Oxford: IRL Press.

HART, G. J. \& Dickinson, F. M. (1982). Kinetic properties of highly purified preparations of sheep liver cytoplasmic aldehyde dehydrogenase. Biochemical Journal 203, 617-627.

Hommel, R. \& Kleber, H.-P. (1990). Properties of the quinoprotein aldehyde dehydrogenase from 'Acetobacter rancens'. Journal of General Microbiology 136, 1705-1711.

JAYASURIYA, G. C. N. (1955). The isolation and characteristics of an oxalate-decomposing organism. Journal of General Microbiology 12, 419-428.

Jirausch, M., Asperger, O. \& Kleber, H. P. (1986). Alcohol oxidation by Acinetobacter calcoaceticus EB 104, a n-alkane-utilizing and cytochrome P-450 producing strain. Journal of Basic Microbiology 26, 351-357.

Kemp, G. D., Dickinson, F. M. \& Ratledge, C. (1988). Inducible long-chain alcohol oxidase from alkane-grown Candida tropicalis. Applied Microbiology and Biotechnology 29, 370-374.

Kleber, H. P., Claus, R. \& Asperger, O. (1983). Enzymologie der n-Alkanoxidation bei Acinetobacter. Acta Biotechnologie 3, 251260.

VAN Der Linden, A. C. \& Huybregste, R. (1969). Occurrence of inducible and NAD(P)-independent primary alcohol dehydrogenase in alkane-oxidizing Pseudomonas. Antonie van Leeuwenhoek 35, 344-360.

MacGibbon, A. K. H., Blackwell, L. F. \& Buckley, P. D. (1977). Kinetics of sheep liver cytoplasmic aldehyde dehydrogenase. European Journal of Biochemistry 77, 93-100.

MaKula, R. \& FinNeRTY, W. R. (1968). Microbial assimilation of hydrocarbons. 1. Fatty acids derived from normal alkanes. Journal of Bacteriology 95, 2102-2107.

MARISON, I. W. \& ATTWOOD, M. M. (1980). Partial purification and characterization of a dye-linked formaldehyde dehydrogenase from Hyphomicrobium X. Journal of General Microbiology 117, 305313.

Michaelis, L. \& Granick, S. (1943). The polymerization of the free radicals of the Würster dye type: the dimeric resonance bond. Journal of the American Chemical Society 65, 1747-1755.

Poels, P. A., Groen, B. W. \& Duine, J. A. (1987). NAD(P) $)^{+}$ independent aldehyde dehydrogenases from Pseudomonas testosteroni. European Journal of Biochemistry 166, 575-579.

SCotT, C. C. L. \& FinneRTY, W. R. (1976). Characterization of intracytoplasmic hydrocarbon inclusions from the hydrocarbonoxidizing Acinetobacter species HO1-N. Journal of Bacteriology 127, 481-489.

Singer, M. E. \& Finnerty, W. R. (1985a). Fatty aldehyde dehydrogenases in Acinetobacter sp. strain HO1-N: role in hexadecane and hexadecanol metabolism. Journal of Bacteriology 164, 1011-1016.

SINGER, M. E. \& FINNERTY, W. R. (1985b). Alcohol dehydrogenases in Acinetobacter sp. strain HO1-N: role in hexadecane and hexadecanol metabolism. Journal of Bacteriology 164, 1017-1024.

Smith, P. K., Krohn, R. I., Hermanson, G. T., Mallia, A. K., Gartner, F. H., Provenzano, M. D., Fujimoto, E. K., Goeke, N. M., OLSON, B. J. \& KLENK, D. C. (1985). Measurement of protein using bicinchoninic acid. Analytical Biochemistry 150, 76-85.

SORGER, D. H. \& AURICH, H. (1978). Mikrobielle Aldehyddehydrogenasen und ihre Bedeutung für die Assimilation aliphatischen 
Kohlenwasserstoffe. Wissenschaftliche Zeitschrift der Karl-MarxUniversitat Leipzig, Mathematisch-Naturwissenschaftliche Reihe 27, $35-45$.

Tassin, J. P., Celier, C. \& Vandecasteele, J. P. (1973). Purification and properties of a membrane-bound alcohol dehydrogenase involved in oxidation of long-chain hydrocarbons by Pseudomonas aeruginosa. Biochimica et Biophysica Acta 315, 220-232.
TAUChert, H., Roy, M., SchöpP, W. \& Aurich, H. (1975). Pyridinnucleotid-unabhängige oxydation von langerkettigen aliphatischen Alkoholen durch ein Enzyme aus Acinetobacter calcoaceticus. Zeitschrift für allgemeine Mikrobiologie 15, 457-460.

Zehr, B. D., Savin, T. J. \& Hall, R. E. (1989). A one-step, low background coomassie staining procedure for polyacrylamide gels. Analytical Biochemistry 182, 157-159. 